\title{
Pressure mounts to strip industry funding from continuing medical education programs
}

Published at www.cmaj.ca on Oct. 22

$\mathrm{P}$ atients hope their doctors will stay abreast of the latest developments in medicine. Does it matter if the doctor heard about a new drug at a dinner sponsored by a pharmaceutical company, or learned the symptoms of an emerging disease in a lecture by an industry scientist?

Yes, say critics in Congress, government and academia, who increasingly brand industry financial support to continuing medical education (CME) as being little more than tainted money, spent to subtly promote drugs or medical devices.

“There's been a progressive, insidious loss of confidence by doctors and by the public in the kind of education being given to doctors who are practising in the community," says Dr. Martin A. Samuels, chairman of the department of neurology at Brigham and Women's Hospital, a teaching affiliate of the Harvard Medical School in Boston, Massachusetts.

Proponents, though, counter that they need the US\$856 million spent by industry last year to finance the courses that most doctors need to keep their medical licences.

Most states require doctors to take about 50 hours of accredited courses annually. There are all sorts of ways to rack up those credits, from studying online to attending a dinner presentation to travelling to a major medical society conference.

Industry money flows to CME providers - whether medical societies, private companies, universities or hospitals - allowing doctors the chance to learn for free or at a discount. In fact, the US Accreditation Council for Continuing Medical Education (ACCME), which is responsible for ensuring that CME courses aren't coloured by companies trying to inflate the market for their own drugs or devices, says that

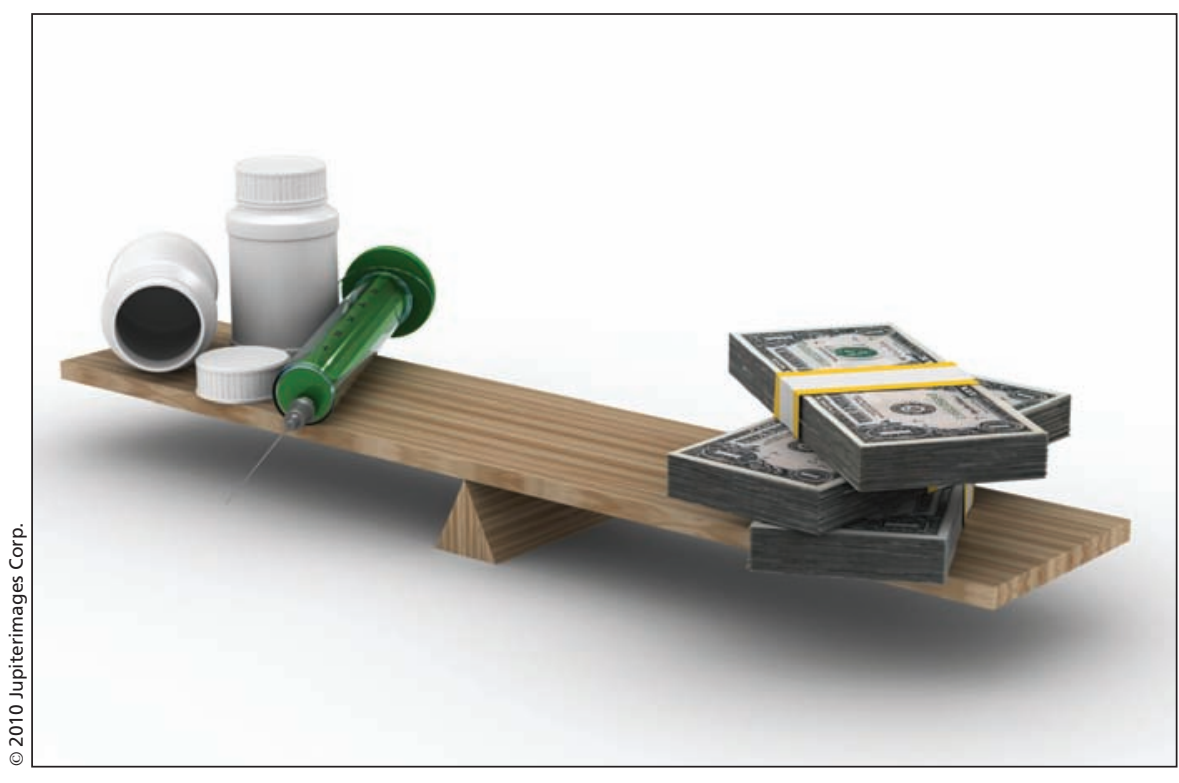

Pharmaceutical industry interests and the academic world's need for money from industry to create continuing medical education programs must be balanced, according to supporters of industry-financed courses.

industry provided almost $40 \%$ of the US $\$ 2.2$ billion spent on accredited courses in 2009. About $60 \%$ of CME providers took industry money.

Dr. Murray Kopelow, ACCME's chief executive officer, says no one suffers illusions about industrial objectives. "Industry is only interested in the optimum use of their products," he says. "They don't care about the optimum use of someone else's products."

ACCME rules state that only CME providers, not drug companies, can control what courses are offered and what information they include. Courses should not promote a specific product, and sources of commercial funding must be disclosed.

Industry's heavy involvement in CME prompted Samuels to create a company in September that will develop materials without industry financing.

It's part of an atmosphere of increased concern about conflict-of-interest between the drug industry and the med- ical community, which prompted the University of Michigan in Ann Arbor to sever its ties to industry dollars. But others, such as the Brody School of Medicine at East Carolina University in Greenville, North Carolina, have sought to more informally wean themselves off corporate cash. Industry support of the school's US\$650 000 CME budget has been slashed to $1 \%$ from $15 \%-20 \%$ over the past five years, says Dr. Stephen Willis, Brody's associate dean for CME, who'd rather see drug companies spend their money on patients in need. Harvard, meanwhile, has imposed a prohibition against more than half of the budget for any CME course coming from a single company.

Drug companies say their support is meant to help doctors learn the latest treatments and sharpen their skills not to push products. Last year, the Pharmaceutical Research and Manufacturers of America updated its ethics code to emphasize that idea. For example, it now says companies' marketing 
departments shouldn't be involved in deciding which courses to finance.

There also appears to some resistance from the medical community itself to the notion that it is so easily influenced.

Doctors were rankled over the summer when a tightening of ACCME policy appeared to deny credit for attending presentations by drug company researchers at major scientific conferences, says Dr. Clyde W. Yancy, then-president of the American Heart Association.

The ruling amounted to "the censoring of industry scientists and the free flow of scientific information," he says. After vigorous protests, ACCME agreed that the association and similar groups that showcase peer-reviewed research could include industry scientists. "This one issue is just a lightning rod that reflects the building tensions that must be resolved between industry and medicine," Yancy notes.

But the notion that doctors are somehow above the influence of industry has been undermined by such developments as the US Justice Department and Department of Health and Human Services allegations that companies have used CME to promote off-label uses of their drugs. AstraZeneca, for example, agreed in April to pay US\$520 million to settle charges that it promoted unapproved uses of the antipsychotic drug quetiapine, partly by influencing the content and speakers in CME programs it sponsored. Eli Lilly and Co. agreed in 2009 to US\$1.415 billion in criminal and civil penalties for promoting unapproved uses of the antipsychotic olanzapine. - Connie O'Connell, Washington, DC

DOI:10.1503/cmaj.109-3693 